\title{
Livelihood Diversification Among Indigenous Peri-Urban Women in the Wa Municipality, Ghana
}

\author{
Ibrahim Abu Abdulai \\ (Corresponding Author) \\ Department of Governance and Development Management, Simon Diedong \\ Dombo University of Business and Integrated Development studies, Wa, Ghana \\ iaabdulai@uds.edu.gh \\ Emmanuel Kanchebe Derbile \\ Department of Planning, Simon Diedong Dombo University of \\ Business and Integrated Development studies, Wa, Ghana \\ Moses Naiim Fuseini \\ Department of Public Policy and Management, Simon Diedong Dombo \\ University of Business and Integrated Development studies, Wa, Ghana
}

DOI//http://dx.doi.org/10.4314/gjds.v18i1.4

\section{ABSTRACT}

Studies on peri-urban development have not paid enough attention to the strategies and dynamics of diversifying livelihoods among indigenous women in the Global South. This paper explores the dynamics of livelihood diversification strategies among indigenous women in response to peri-urban development in Wa, Ghana. The mixed-methods design guided the study, while the sample consisted 399 respondents selected from a sample frame of 1494 women. Data analyses involved descriptive statistics, non-parametric and thematic analyses. The study found that peri-urban development had led to the loss of access to farmland among indigenous women. In response, women have resorted to switching from farm-based to non-farm-based livelihoods amidst multiple production challenges. There is, therefore, the need to support the sustainability of women's livelihoods through the Municipal Assembly and, in particular, through policy interventions such as support for skills training and financial support to enable indigenous people to make a sustainable living. 
Keywords: Diversification, Ghana, Livelihoods, Peri-Urbanization, Women

\section{INTRODUCTION}

The peri-urban area provides accommodation for people seeking to settle in the urban areas due to its proximity to the city and relatively low land rent. Demographic changes, migration of workers to urban areas, economic growth, and globalisation, the presence of job opportunities in the city and relatively easy connections to the city as well as weak state institutions primarily drive peri-urban development (Marshall \& Randhawa, 2017; Woltjer, 2014). Peri-urban development is also because of the desire for large homes, institutional weaknesses, construction of utilities and roads in peri-urban areas, which tends to create landlessness and disruption of livelihoods among indigenous residents, particularly, women because of land conversion (He et al., 2009; Tassie, 2018). The conversion of periurban agricultural lands into permanent uses, such as residential, commercial, and industrial uses, tends to undermine agricultural-based livelihoods and disempower the people, especially women, as they will no longer have access to land and its resources. As indicated by the empowerment theory, unequal distribution of and access to land creates poverty among the disadvantaged sub-groups such as women (Woltjer, 2014).

Therefore, the equal distribution and access to societal resources such as land to indigenous peri-urban women could empower them to undertake sustainable livelihoods for themselves and their households (Zimmerman, 2000). However, the role of resources in the process of empowerment could only be realised if the affected have the appropriate skills, capabilities to recognise and utilise the resources in ways that enable them to secure sustainable income and diversify their livelihoods (He et al., 2009). According to Chambers and Conway (1992), livelihood comprises the capabilities, assets and activities required for a means of living. Thus, livelihood diversification entails the different livelihood activities undertaken by an individual or a household to make a living (Ellis \& Allison, 2004). The activities undertaken by these individuals are dependent on their capabilities and capacity to transition from practised livelihoods to adopted livelihoods (Sen, 2004).

It is important to note that peri-urban development generates opportunities for non-agricultural employment such as small business, service-oriented jobs, commercial and manufacturing, which residents including indigenous women, can earn income (Rafferty, 2009; Rijanta, 2006). However, indigenous households' involvement, especially women, depends on their linkage to agriculture and the 
perceived social outcome since such families may not have the requisite skills or qualifications to participate in urban sector jobs (Rijanta, 2015). Accordingly, social actors make choices based on the constraints, importance, and value and then select the best alternative to yield maximum outcome (Burns \& Roszkowska, 2016). Therefore, the choice of livelihoods of indigenous women depends on their access to resources such as land, skills and their ability to resolve the constraints therein in their quest to make a living in the face of urban encroachment on peri-urban agricultural lands.

However, the phenomenon of patriarchy in sub-Saharan Africa and most countries in the Global South tends to disadvantage women over men because of ethnicity, sex, low literacy rate, and rural residency patterns (Habib et al., 2019). The consequences of patriarchal social codes and beliefs created unequal indigenous women's access to productive resources like land, property, housing, and the right to education and paid employment (Kuusaana et al., 2013), which limits their capability to undertake diversified livelihood activities to transition out of poverty (Habib et al., 2019). Given this, peri-urbanisation and the associated rapid land conversion coupled with these overlapping challenges indigenous women in the sub-Saharan African context and most patriarchal societies are confronted will push many of them out of farming and short-circuit indigenous livelihoods.

Nevertheless, previous studies (Appiah et al., 2017; Peprah, 2014) in several countries in the global south showed little, if any, evidence of the impact of peri-urbanisation on the livelihood of indigenous peri-urban women and how they are coping with the situation that requires alternative skill to diversify their livelihoods. For instance, Peprah (2014) indicated that the conversion of agricultural lands into nonagricultural uses in peri-urban Wa had led to the adoption of non-farm livelihood activities. However, the study did not address how peri-urban expansion affects indigenous women's access to land for farming. Oduro et al. (2015) also investigated the livelihood adaptation strategies of residents in peri-urban areas in Accra, but this study did not also explore the livelihood strategies pursued by indigenous women and the associated challenges. Appiah et al. (2017) examined factors that influence agricultural land uses in peri-urban Asante-Akim South District of Ashanti Region, Ghana. This study also stopped short of analysing how these decisions affected livelihood of indigenous women. Therefore, it is crucial to isolate periurban indigenous women and examine how they respond to urban change and new livelihood requirements. This would enable the women to adapt to farmland loss by taking advantage of the opportunities while resolving the constraints as they encounter urban pressures. Consequently, the motivation for the study 
is to investigate the influence of peri-urban development on the livelihood diversification of indigenous peri-urban women in Wa, Ghana. Specifically, the study sought to address the following related research objectives: (i) To determine the state of indigenous peri-urban women's access to land for farming; (ii) To examine the livelihood diversification activities of indigenous peri-urban women; and (iii) To explore the challenges associated with indigenous peri-urban women's quest for livelihood diversification.

\section{LITERATURE REVIEW}

\section{Theoretical Perspective}

The assumptions of empowerment and rational choice theories serve as the foundation for this research. The empowerment theory establishes a connection between an individual's well-being and the social and political forces. The theory is concerned with how poor and marginalised people achieve access to and manage vital resources necessary for survival (Perkins \& Zimmerman, 1995). Thus, a society's activities, behaviours, and social processes can be inspiring or disempowering. A person's empowerment outcomes can involve a sense of situational autonomy and resource mobilisation abilities, while group empowerment outcomes may provide proof of available neighbourhood services (Perkins \& Zimmerman, 1995). Consequently, empowerment occurs because of individual and concerted social action (Pigg, 2002). Within the empowerment debate, the central question is whether when women have access to land, labour, schooling, and job opportunities, it increases or decreases their ability to diversify their livelihoods. The issue is critical in light of declining arable land supply in peri-urban areas as women seek subsistence diversification (Sudan, 2007). Utilising the theory to analyse livelihood diversification strategies of indigenous peri-urban women suggests that access to essential assets such as land, education, and employment opportunities are essential to diversify.

In comparison, the rational choice theory maintains that in a decision case, an individual or mutual entity selects or determines alternate acts or sequences of actions or his or her repertoire of available alternatives, which are both feasible and unambiguously identified (Burns \& Roszkowska, 2016). The principle asserts that an individual decides the effects of each choice, the potential payoffs associated with the choices and that the actor is presumed to be mindful of all practical consequences associated with his/her alternative acts (Burns \& Roszkowska, 2016; Sato, 2010). If confronted with a decision-making condition, an agent considers a 
finite number of alternatives, assigns them consequences, prioritises and values these consequences, and makes the best option among the possible alternatives (Burns \& Roszkowska, 2016; Dekker, 2017). Accordingly, the rational decision behaviour is motivated by the individual's (self-) interest in the results as one perceives or defines (Burns \& Roszkowska, 2016). The actor measures the costs and advantages of different choices, relying primarily on the implications for herself and choosing the one with the more tremendous net advantage or "utility" (Burns \& Roszkowska, 2016; Sato, 2010; Dekker, 2017). The rational choice theory has been incorporated in business decisions about productivity, output, spending, and technical transformation, personal and household choices about consumption and savings (Burns \& Roszkowska, 2016). Thus, it helps to explain how indigenous women will handle livelihood diversification decisions.

\section{Urbanisation in the Wa Municipality}

This section of the paper presents a review of the population growth trend and physical expansion of Wa since the 1970s. The population of Wa has been increasing since the 1970s. According to the Ghana Statistical Service (GSS) (2013), 13,740 people lived in Wa in 1970, while in 1984, 36,067 people resided in the town. In 2000, the total inhabitants of Wa were 66,644, while 71,051 lived in Wa in 2010 (GSS, 2013). The rapid growth in population recorded in 1984 in Wa could be attributed to the establishment of Wa as a regional capital of the Upper West Region in 1984 (Ahmed et al., 2020). Therefore, as a regional capital, there was the need for the provision of services, which led to establishing several decentralised state offices in Wa (Ahmed et al., 2020). The establishment of tertiary educational institutions (i.e., Nusrat Jahan Ahmadiyya College of Education, Faculty of Integrated Development Studies of University for Development Studies, the Wa Polytechnic and a Nursing Training School) are sources of attraction to both professionals and non-professionals to the town (Ahmed et al., 2020).

Because of the town's increased population, the built-up area has also increased, leading to its physical expansion. To understand the dynamics of the built-up areas in Wa 1986 was used as the base year because Wa became the Upper West Region's capital in 1983 and the structural plan of Wa was designed in 1985. Osumanu et al. (2018) reported that from 1986 to 2016, the built-up area of the Wa Municipality increased by more than $100 \%$ (Figure 1). They further indicated that the built-up areas of the municipality increased by $50.6 \%$ between 1986 and 2001. While the built-up area grew by $35.1 \%$ from 2001 to 2014 , the growth from 2014 to 2016 was much higher (49.8\%) than the previous period (Osumanu et al., 2018). Eledi and 
Kuusaana (2014) had earlier reported that Wa started experiencing rapid growth in the built-up area in 2005. This hints that peri-urban agricultural lands that local people depended on for their livelihoods may be under threat from the city's physical expansion.

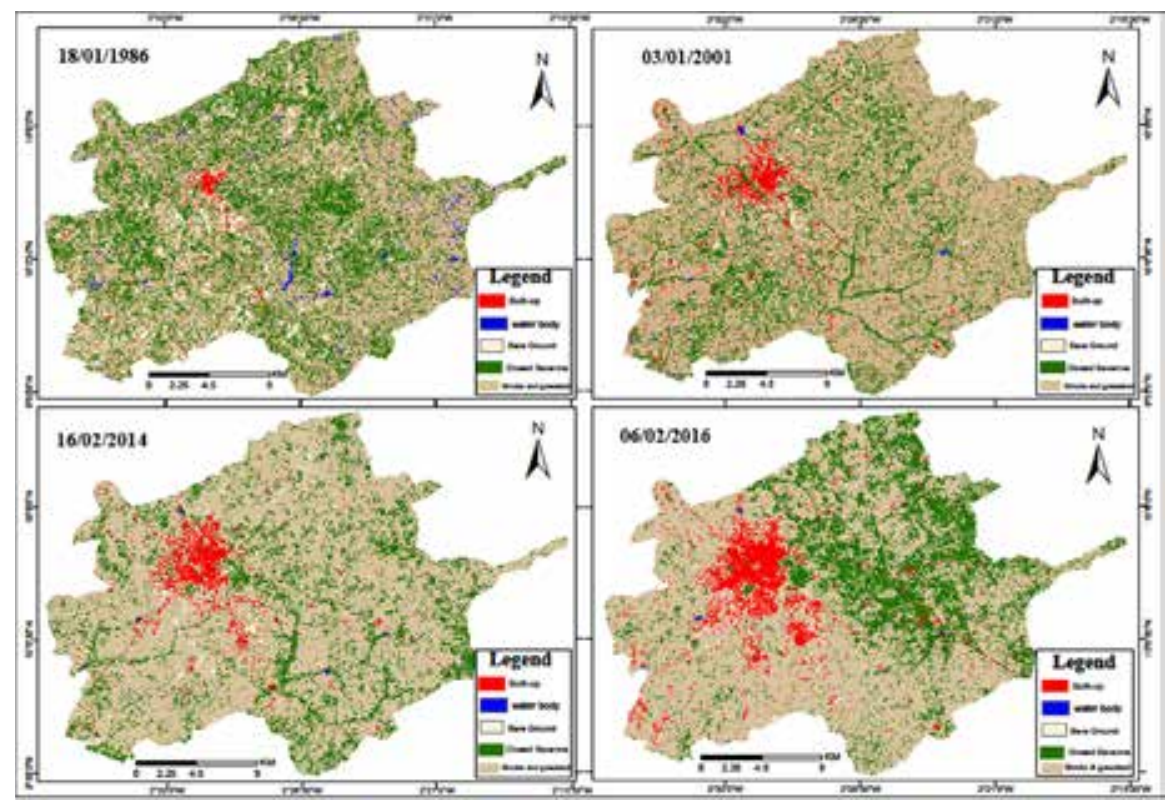

Figure 1: Physical expansion of Wa from 1986 to 2016

Source: Adopted from Osumanu et al. (2018, p.12)

\section{Peri-urban Development, Gender and Livelihood Diversification}

According to Adell (1999), the peri-urban area is a transitional zone between the city and the countryside. Thus, the location is characterised by rural and urban characteristics, new land uses, smaller farmlands and new occupations for indigenous residents and the newcomers (Marshall \& Randhawa, 2017). Speculators and their local allies, and private individuals seeking land for residential, industrial, commercial, real estate and infrastructure development trigger this transformation in the peri-urban areas (Marshall \& Randhawa, 2017). Rafferty (2009) argues that the construction of public infrastructure such as utilities, schools, offices, and roads in peri-urban areas reflects society's economic growth. On the other hand, capitalism's effect on peri-urban development manifests in capital flow into the built environment for both production and consumption from profit-seeking individuals and organisations (Scott, 2007). However, peri-urban areas are often bereft of essential services such as water, sanitation, or health facilities (Marshall 
\& Randhawa, 2017). Besides, peri-urban land transition reduces the land available for agricultural and its related livelihoods, which indigenous residents, particularly women, had previously depended on to make a living (Olsson et al., 2016).

The capabilities, tangible and non-tangible assets, and activities required for a living constitute livelihood (Chambers \& Conway, 1992). A livelihood is sustainable when it can cope with and recover from stresses and shocks and maintain or enhance its capabilities, assets, and activities both now and in the future, while not undermining the natural resource base (Chambers \& Conway, 1992). Livelihood diversification entails constructing a diverse portfolio of activities and social support systems to improve households' living standards (Ellis, 2000). Generally, households employ livelihood diversification as an adaption strategy for challenges emerging from rapid peri-urban land conversion (Ellis \& Allison, 2004; Gebru et al., 2018). However, Angeles and Hill (2009) argue that gender plays a significant role in livelihood choices and opportunities in peri-urban communities. It is argued that women are more capable of undertaking small-scale enterprises to spread their economic activities and income sources to cope with changing circumstances than their male counterparts (Sudan, 2007). Yet, restricted access to land, loans and credit hinders women's livelihood diversification efforts (Angeles \& Hill, 2009).

In peri-urban areas, households engage in farm and non-farm livelihood strategies in response to peri-urban development (Tassie, 2018). However, it is crucial to note that people diversify their livelihoods for several reasons, including the absence of specialization, low income from farming and unavailability of surplus labour (Gebru et al., 2018). The families with people living in poverty diversify for survival, whereas the better-of households diversify for wealth accumulation and better living (Gebru et al., 2018). Dinku (2018) contributes that livelihood diversification can facilitate poverty reduction, especially among indigenous women in peri-urban areas. The everyday livelihood activities of peri-urban dwellers in the global south include weaving, self-employment, small businesses, casual labour, sale of wood, charcoal or stones (Wegedie, 2018). Construction-related skill sets such as masonry, carpentry, electrical trade, and metal works are also necessary new skills required to make a living in the peri-urban environment (Wegedie, 2018). 


\section{METHODOLOGY}

\section{Study Setting}

The study was conducted in three randomly selected peri-urban communities (Danko, Nakori and Sombo) of Wa Municipality. Wa is the capital of the Wa Municipality and the capital of the Upper West Region of Ghana. The municipality is surrounded to the north by Nadowli District, Wa East District to the east and Wa West District to the west and the south. Figure 2 shows the study communities within the context of the country, region and municipality. The municipality residents undertake a diversity of livelihood activities including services, farming, transport, tourism, communication and energy. The municipality had $49.7 \%$ males and $51.3 \%$ females as of 2010 (GSS, 2014). GSS (2014) also estimated that more than $34 \%$ of the municipality population resided in rural localities, while the majority $(56 \%)$ resided in an urban locality, which is Wa.

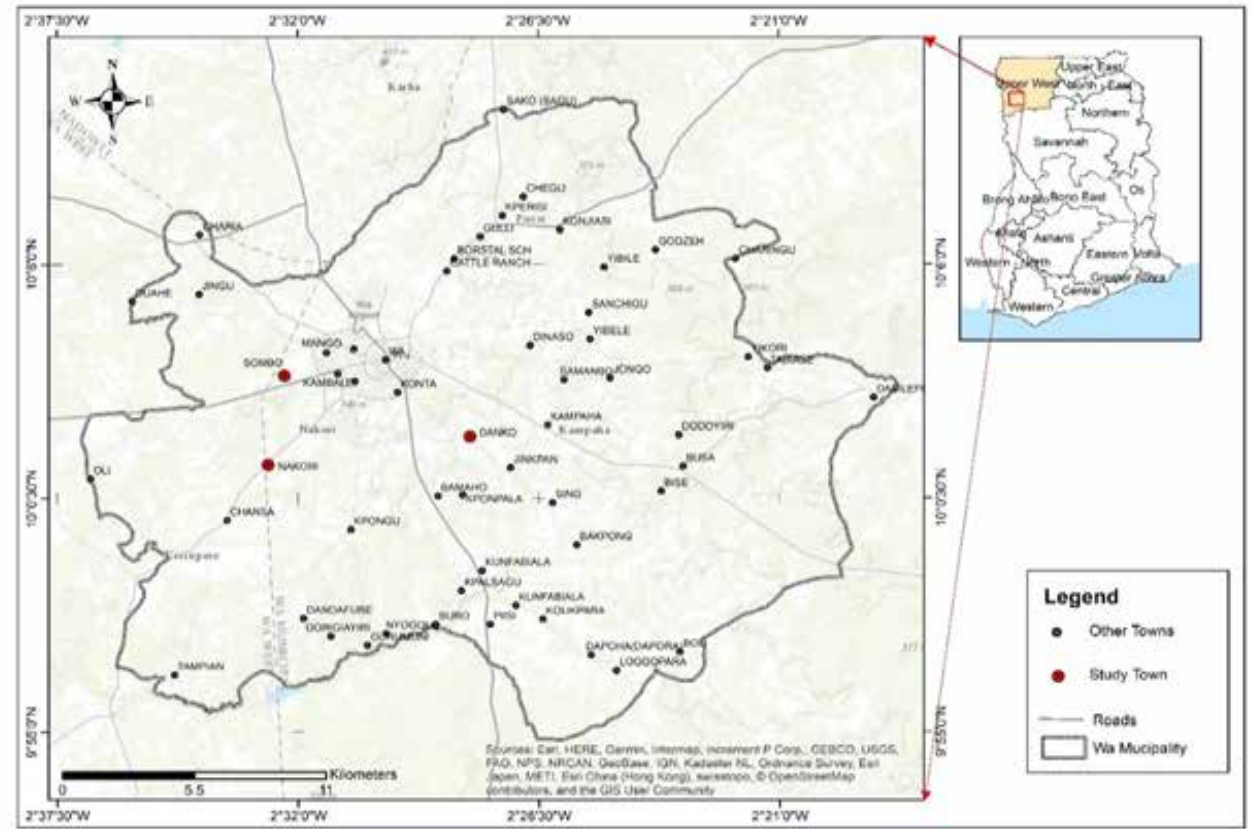

Figure 2: Study communities in the context of the Wa Municipality

Source: Adapted from GSS (2014) 


\section{Research Design and Sampling}

The study adopted the mixed research approach, which involves using quantitative and qualitative methods to address the research objectives (Creswell, 2014). The approach provides the opportunity to collect, analyse, integrate and interpret quantitative and qualitative data to understand peri-urban development better, agriculture and livelihood diversification (Creswell, 2014; Johnson \& Onwuegbuzie, 2004). The choice of this strategy of inquiry was to enable the researchers to conduct a quick assessment of the livelihood strategies of indigenous women in peri-urban Wa by collecting both quantitative and qualitative data simultaneously and integrating them in the analysis to facilitate better comprehension of the issues of livelihood of indigenous women in the study area.

A simple random sampling technique aided in selecting Danko, Nakori and Sombo from the six peri-urban communities (Mangu, Sombo, Kpongu, Nakori, Danko, and Bamahu-Kompala) using the fishbowl method without replacement. The selection was to ensure representation of the indigenous peri-urban households in Wa. The sampling frame of indigenous households was from the Community Health Planning Services zones in the communities. In all, there were 1,494 indigenous households. The sample size was then calculated using:

$\mathrm{n}=\mathrm{N} /\left[\left(1+\mathrm{N}(\mathrm{e})^{2]}\right.\right.$

Where $\mathrm{n}=$ sample size, $\mathrm{N}=$ sample population, and $\mathrm{e}=$ margin of error [0.05]. Therefore, $n=1,494 /$ [ $1+1494$ (.05)2] was equal to 399. The number of respondents (399) was then proportionally allotted to the communities (i.e., Danko $=225$, Nakori $=58$, and Sombo $=116)$ using stratified random sampling. The researchers also applied a purposive sampling technique to choose one key informant and 18 focus group discussants (total qualitative sample is 19). The purposive sampling technique involves the deliberate selection of an informant (s) because of the rich information they possess. The technique was used to select key informants from the Physical Planning Department of the Wa Municipality Assembly and indigenous women leaders (six in each community) as focus group discussants.

\section{Data Collection Instruments and Analytical Procedures}

A household survey was carried out using a questionnaire to collect data from indigenous peri-urban women. The questionnaire contained items that sought to collect data on respondents' background characteristics, perception of periurban development, and the effects of peri-urban development on their access 
to land. The rest were livelihood diversification strategies pursued to cope with rapid agricultural land conversion and the challenges therein. The questionnaire contained both closed-ended and open-ended items responded to by the women via a face-to-face interview. An interview guide was also used to elicit qualitative data from a key informant from the Physical Planning Department of the Wa Municipal Assembly. In contrast, a focus group discussion (FGD) guide was deployed to collect data from three women groups (one in each community). The combination of a questionnaire, key informant interviews and focus group discussion was to ensure data triangulation.

The researchers utilised descriptive statistics, cross tabulation, chi-square test of independence and Wilcoxon signed-ranked test to analyse the quantitative data. The chi-square test of independence was used to determine whether differences existed concerning livelihood diversification. For the Wilcoxon signed-rank test, it was used to analyse paired data in a single sample to assess whether there was a difference in their population mean ranks. Wilcoxon signed-ranked test was used to analyse the quantitative data on the respondents' income because the data violated the normality principle. The entire statistical tests were conducted at the $5 \%$ level. On the other hand, key informant interviews and FGD were analysed by identifying, and categorising the issues into themes using a manual coding approach.

\section{RESULTS AND DISCUSSION}

\section{Peri-urban Development and Indigenous Peri-urban Women's Access to Farmland}

This section focuses on perception about peri-urban development and its drivers as well as women's land access. Since Wa Municipality and Wa town, in particular, started experiencing rapid physical expansion and encroachment on peri-urban areas from 2005 (Eledi \& Kuusaana, 2014), it is essential to know respondents' perception about the peri-urbanisation in the area as this will inform indigenous women's livelihoods choices in response to the dwindling farmlands. The results (Table 1) showed that $96 \%$ of the respondents indicated they had observed some visible changes in their respective communities since 2005 , while the rest did not observe changes in the peri-urban environment.

As respondents indicated, they had witnessed some changes within their communities; it was crucial to know the specific changes they had observed over the period. In Table 1, out of the multiple responses, more of them cited increased 
residential housing ( $86.5 \%)$, followed by increased service infrastructure $(64.5 \%)$, and then followed by reduced farmlands (60.2\%) as a manifestation of peri-urbanisation. During an interview with a key informant from the Physical Planning Department of the Wa Municipality (September 20, 2019), and a review of the physical development plans of Wa, it emerged that government developed the first structural physical plan of Wa in 1985. As such, the increase in the build-up areas was noticeable by 1986. The finding is also similar to earlier literature that the rapid conversion of agricultural lands characterises peri-urban areas into residential accommodation in Kumasi and Wa (Osumanu et al., 2018).

Table 1: Perception of peri-urban development since 2005

\begin{tabular}{|l|l|l|}
\hline Perceptions of changes in the peri-urban environment & Number & $\%$ \\
\hline Change has occurred & 383 & 96 \\
\hline No changes have occurred & 16 & 4 \\
\hline Total & 399 & 100 \\
\hline Manifestations of peri-urban Development & Number & $\%$ \\
\hline Increased Residential Housing & 345 & 86.5 \\
\hline Increased Service Infrastructure & 261 & 64.5 \\
\hline Reduced Farmlands & 240 & 60.2 \\
\hline Increased Population & 232 & 58.1 \\
\hline Increased Physical Infrastructure & 174 & 43.6 \\
\hline Source: Field survey (2019) & &
\end{tabular}

The study identified the drivers that may have led to peri-urbanisation. In Table 2 , of the multiple responses cited, increased demand for land (66.9\%) and natural population increase (52.6\%) appeared as the primary drivers of periurban development. These drivers tend to limit women's access to land, thereby disempowering them as claimed by the empowerment theory (Perkins \& Zimmerman, 1995).

Table 2: Drivers of peri-urban development

\begin{tabular}{|l|l|l|}
\hline Reasons for peri-urban development & Number & $\%$ \\
\hline Increased demand for land & 267 & 66.9 \\
\hline Natural population increase & 210 & 52.6 \\
\hline Migration to the town & 122 & 30.6 \\
\hline
\end{tabular}


During an interview with a key informant from the Physical Planning Department of the Wa Municipality (September 20, 2019), he stated that "high rent in the suburbs such as Wapaani, Sokpayiri, Kabanye and others have compelled tenants to acquire land in peri-urban areas to build their own houses instead of renting." This had led to the rapid conversion of farmlands into residential accommodation in these communities. This was corroborated during a FGD with indigenous women in Danko that several completed houses are not occupied or partially occupied in the community that they attributed to the relatively cheap cost of land in the community. It suggests that even though there had been a rapid conversion of agricultural lands into residential housing in the peri-urban areas, the houses are not fully used; however, there is a denial of indigenous women's land access for farming. The results also indicate that population growth is not the prime driver of peri-urban development, but individuals' desire to own houses. The finding contradicts earlier literature that increased population in the urban core is the central driver of peri-urban development and consequently loss of agricultural lands in these areas (Woltjer, 2014).

The study sought to ascertain whether peri-urban development had affected indigenous women's access to land for farming activities. From the results, an overwhelming majority (91\%) of respondents stated that peri-urban development had limited access to land for farming purposes. Historical analysis of the results (Table 3) showed a majority (70.4\%) of respondents reported they had access to a large parcel of land for farming purposes in 2005. Still in 2019, the percentage of the same cohort of women with access to a large parcel of land for the same purpose dropped by $65 \%$ over the 14 years. The results are even more revealing for women who do not have access to land. The number and percentage of women of the same cohort reporting lack of land for farming purposes increased from 25(6.3\%) in 2005 to $223(55.9 \%)$ in 2019 . As women lose access to land, it may perhaps disempower those without professional skills; as such, it could push them into the poverty trap (Zimmerman, 2000). He et al. (2009) also reported a similar finding that peri-urban development creates landlessness among indigenous farm households in China. 
Table 3: Access to land for farming

\begin{tabular}{|l|l|l|l|l|}
\hline \multirow{2}{*}{ Land Access } & \multicolumn{2}{|l|}{2005} & 2019 \\
\cline { 2 - 5 } & Number & $\%$ & Number & $\%$ \\
\hline No land & 25 & 6.3 & 223 & 55.9 \\
\hline Less land (1-3 acres) & 93 & 23.3 & 158 & 39.6 \\
\hline Large land (4+ acres) & 281 & 70.4 & 18 & 4.5 \\
\hline Total & 399 & 100 & 399 & 100 \\
\hline
\end{tabular}

Source: Field survey (2019)

Access to land was disaggregated by marital status (Table 4). The results showed that in 2005 most of the married (70.9\%) and single $(65.9 \%)$ held the view that they had access to large land for farming. However, in 2019, most married (58.4\%) indicated they had no land, while $65.9 \%$ of those who are single reported they had less land for farming. In effect, land access reduced from 2005 to 2019 according to both married and single women. Married women who lacked property meant that their husbands might have taken it from them due to their land being lost to periurban growth.

Table 4: Land access by marital status

\begin{tabular}{|c|c|c|c|}
\hline \multirow[t]{2}{*}{ Land Access } & \multicolumn{3}{|c|}{ Marital Status } \\
\hline & Married & Single & Total \\
\hline \multicolumn{4}{|l|}{2005} \\
\hline No land & $22(6.1 \%)$ & $3(7.3 \%)$ & $25(6.3 \%)$ \\
\hline Less land (1-3 acres) & $82(22.9 \%)$ & $11(26.8 \%)$ & $93(23.3 \%)$ \\
\hline Large land $(4+$ acres $)$ & $254(70.9 \%)$ & $27(65.9 \%)$ & $281(70.4 \%)$ \\
\hline Total & $358(100 \%)$ & $41(100 \%)$ & $399(100 \%)$ \\
\hline \multicolumn{4}{|l|}{2019} \\
\hline No land & $209(58.4 \%)$ & $14(34.1 \%)$ & $223(55.9 \%)$ \\
\hline Less land (1-3 acres) & $131(36.6 \%)$ & $27(65.9 \%)$ & $158(39.6 \%)$ \\
\hline Large land (4+ acres) & $18(5.0 \%)$ & $0(0.0 \%)$ & $18(4.5 \%)$ \\
\hline Total & $358(100 \%)$ & $41(100 \%)$ & $399(100 \%)$ \\
\hline
\end{tabular}

Source: Field survey (2019)

Historically, Ghana's customary practices have tended to be biased against women in accessing land even through the market (Kuusaana et al., 2013). As such, we sought to find out how they could secure land for farming activities in the past. The results showed that people secured land access for farming via the spouse, relatives, 
inheritance or buying. Since most (55.9\%) of the respondents noted that they have no access to land now, it was crucial to know what had led to their inability to access land for farming. The results indicated that $83.5 \%$ of the respondents stated the land they were farming had been sold out to private developers, while the rest noted that the portion they were farming on had houses family members had built. This suggests that the women do not have control over land, and as such, it limits their access to land and other productive assets (Adesoji et al., 2014). This situation disempowers indigenous women since they do not have access to or have limited access to land. The unequal distribution of and access to resources such as land between men and women may push the vulnerable, particularly indigenous women, into poverty (Zimmerman, 2000). This is because the indigenous women will not be able to farm. After all, they do not have control over lands, which were hitherto used for farming. The situation was because of the taking over the land by their spouses because of the conversion of nearby lands the men farmed.

As most of the respondents had no land access for farming, it was imperative to discern whether the lack of land access affected their livelihoods. The results (Table 5) showed that out of the multiple responses, more than two-third cited the loss of farm income $(70.9 \%)$ and reduced crop yield $(49.1 \%)$ as the effects of lack of access to land for farming purposes. This implies that most women had suffered a loss of farm income and reduced crop yield because of their inability to access land or limited land access for farming purposes. It suggests that indigenous women had lost the opportunity to earn income from farming activities as peri-urban development generates pressure on peri-urban resources and erodes indigenous farm households' livelihoods.

Table 5: Effects of land access on farming

\begin{tabular}{|l|l|l|}
\hline Effect & Number & $\%$ \\
\hline Loss of farm income & 283 & 70.9 \\
\hline Reduced crop yield & 196 & 49.1 \\
\hline Unemployment & 92 & 23.1 \\
\hline Source: Field survey (2019) &
\end{tabular}

\section{Livelihood Assets and Diversification}

This section discusses assets, livelihood diversification strategies of indigenous women, the reasons that informed livelihood strategies and challenges to diversification. Livelihood diversification requires some primary assets to facilitate the process. In this regard, it was crucial to ascertain the respondents' assets that 
could enable them to diversify their livelihood activities. It emerged that the respondents, generally, had assets such as labour, access to common property natural resources (i.e., stones, economic tress etc.), access to markets, and savings. These assets laid the pedestal for some of them to diversify their livelihoods via investing in non-farm enterprises as methods of making a living.

The study examined the livelihood activities indigenous women engaged in as of 2005 and in 2019. The results (Table 6) showed that in 2005, 87\% of the respondents were engaged in farm livelihood strategies like the cultivation of crops (groundnuts, beans), vegetables (okro, pepper and tomatoes) and animal rearing. The rest (13\%) of the respondents revealed they were involved in non-farm livelihood activities such as stone mining, petty trading, and charcoal making. On the other hand, for 2019 , the results showed that $72.7 \%$ of the respondents were engaged in non-farm activities (stone mining, petty trading and charcoal making), while the rest $(27.3 \%)$ were still involved in farm activities (food crop farming and animal rearing).

Table 6: Past and current livelihood activities of indigenous peri-urban women

\begin{tabular}{|l|l|l|l|l|}
\hline \multirow{2}{*}{ Activity } & \multicolumn{2}{|l|}{2005} & $\%$ & 2019 \\
\cline { 2 - 5 } & Number & $\%$ & Number & $\%$ \\
\hline Farm & 347 & 87 & 109 & 27.3 \\
\hline Non-farm & 52 & 13 & 290 & 72.7 \\
\hline Total & 399 & 100 & 399 & 100 \\
\hline
\end{tabular}

Source: Field survey (2019)

Respondents' livelihood diversification was classified according to their educational level, as schooling has been seen to impact how livelihoods are diversified. The findings (Table 7) indicated that most educated and uneducated individuals were engaged in farm-based livelihoods in 2005. This may be because they possessed land (see Table 3 and 4). Nonetheless, in 2019, the majority of respondents educated or not diversified their livelihoods beyond farming. This was attributed to property depletion. The finding that, regardless of educational level, livelihood diversification was chosen as land became inaccessible reinforces the rational choice theory's claim that actors (i.e., educated and uneducated individuals) are rational and, as such, making choices with the greatest utility (Burns \& Roszkowska, 2016; Dekker, 2017). 
Table 7: Educational status by livelihood diversification

\begin{tabular}{|l|l|l|l|}
\hline \multirow{2}{*}{ Educational Status } & Livelihood & Non-farm & Total \\
\cline { 2 - 4 } & Farm & & \\
\hline 2005 & & $8(11.0 \%)$ & $73(100 \%)$ \\
\hline Basic school & $65(89.0 \%)$ & $8(21.1 \%)$ & $38(100 \%)$ \\
\hline Middle/Junior High school & $30(78.9 \%)$ & $4(13.3 \%)$ & $30(100 \%)$ \\
\hline Senior High School & $26(86.7 \%)$ & $2(10.0 \%)$ & $20(100 \%)$ \\
\hline Tertiary & $18(90.0 \%)$ & $30(12.6 \%)$ & $238(100 \%$ \\
\hline Not educated & $208(87.4 \%)$ & $52(13.0 \%)$ & $399(100 \%)$ \\
\hline Total & $347(87.0 \%)$ & & \\
\hline 2019 & & $52(71.2 \%)$ & $73(100 \%)$ \\
\hline Basic school & $21(28.8 \%)$ & $32(84.2 \%)$ & $38(100 \%)$ \\
\hline Middle/Junior High school & $6(15.8 \%)$ & $22(73.3 \%)$ & $30(100 \%)$ \\
\hline Senior High School & $8(26.7 \%)$ & $14(70.0 \%)$ & $20(100 \%)$ \\
\hline Tertiary & $6(30.0 \%)$ & $170(71.4 \%)$ & $238(100 \%$ \\
\hline Not educated & $68(28.6 \%)$ & $290(72.7 \%)$ & $399(100 \%)$ \\
\hline Total & $109(27.3 \%)$ & & \\
\hline
\end{tabular}

Source: Field survey (2019)

The research examined the degree to which respondents' marital status could affect their livelihood diversification path. According to Table 8, most married (86.6\%) and single women (90.2\%) reported being engaged in farm activities in 2005. This was because the land was still plentiful. A chi-square measure of independence was used to determine if there were disparities in livelihood diversification (i.e. farm and non-farm activities) by marital status. At the 0.05 alpha standard, this was not statistically important $\left(x_{2}=0.171, d f=1, p\right.$-value $\left.=0.680\right)$. This indicates that there was little disparity in the diversification of livelihoods between married and single women. By 2019, however, the situation had shifted. This is because, during this time, the majority of married (72.1\%) and single women (78\%) diversified their livelihoods into non-farm businesses, most likely due to little or no access to land for farming purposes (see Table 3 and 4). A chi-square measure of independence was used to determine if there were variations in livelihood diversification according to marital status in 2019. This was not statistically significant ( $X_{2}=0.396, d f=1, p$-value $=0.529$ ) at the 0.05 alpha level. This demonstrates that there was little disparity between the livelihood diversification opportunities available to married and single women. Both married and single women rationally choose a non-farm business because it would allow them to achieve their goals, as the rational choice principle argues (Burns \& Roszkowska, 2016). 
Table 8: Marital status by livelihood diversification

\begin{tabular}{|l|l|l|l|}
\hline \multirow{2}{*}{ Marital Status } & \multicolumn{4}{|l|}{ Livelihood } & Non-farm & Total \\
\cline { 2 - 4 } & Farm & & \\
\hline 2005 & & $48(13.4 \%)$ & $358(100 \%)$ \\
\hline Married & $310(86.6 \%)$ & $4(9.8 \%)$ & $41(100 \%)$ \\
\hline Single & $37(90.2 \%)$ & $52(13.0 \%)$ & $399(100 \%)$ \\
\hline Total & $347(87.0 \%)$ & & \\
\hline 2019 & & $258(72.1 \%)$ & $358(100 \%)$ \\
\hline Married & $100(27.9 \%)$ & $32(78.0 \%)$ & $41(100 \%)$ \\
\hline Single & $9(22.0 \%)$ & $290(72.7 \%)$ & $399(100 \%)$ \\
\hline Total & $109(27.3 \%)$ & & \\
\hline
\end{tabular}

Source: Field survey (2019)

Note: Significant at 0.05 alpha level; 2005 test statistics $-x^{2}=0.171, d f=1, p$-value $=$ $0.680 ; 2019$ test statistics $-X^{2}=0.396, d f=1, p$-value $=0.529$

The results illustrate that most of the respondents had diversified their livelihoods from agriculture to non-farm enterprises as they encountered peri-urban pressures. This means that even though farming remains a livelihood activity, its importance had declined among indigenous per-urban women since they have added on more non-farm activities to complement farm income. The findings on a shift from agriculture to non-farm livelihoods depart from Woltjer's (2014) work that indicated that agricultural activities in peri-urban areas tend to persist under pressures from urban activities in developing countries.

Individuals choose a variety of livelihoods depending on their social background or other factors. It was also important to understand the motivations for aboriginal people to engage in subsistence practices. The findings (Table 9) revealed that $60.7 \%$ of respondents diversified their livelihoods in order to survive, $26.1 \%$ diversified because they lacked the expertise necessary to pursue high-paying careers. The remainder ( $9.6 \%$ and $4 \%$, respectively) diversified due to the poor income they earned from farming and capital accumulation. According to the rational choice theory, the respondents' choices on livelihood diversification are dictated by the benefits they anticipate (Burns \& Roszkowska, 2016). 
Table 9: Reasons for livelihood diversification

\begin{tabular}{|l|l|l|}
\hline Reason & Number & $\%$ \\
\hline Survival & 241 & 60.7 \\
\hline Lack of skills & 104 & 26.1 \\
\hline Low farm income & 38 & 9.6 \\
\hline Wealth accumulation & 16 & 4.0 \\
\hline Total & 399 & 100 \\
\hline
\end{tabular}

Source: Field survey (2019)

Moreover, the causes for livelihood diversification were examined in relation to marital status (Table 10). The findings indicated that the majority of married women cited survival (60.1\%), a lack of expertise (25.8\%), and a low income (10.4\%) as reasons for diversifying their livelihoods. Similarly, single women cited survival (65.9\%) and a lack of expertise as their primary concerns (29.3\%). Thus, there was no difference in the explanations for livelihood diversification according to marital status.

Table 10: Marital status by reasons for livelihood diversification

\begin{tabular}{|l|l|l|l|}
\hline \multirow{2}{*}{ Reason } & \multicolumn{3}{|l|}{ Marital Status } \\
\cline { 2 - 4 } & Married & Single & Total \\
\hline Survival & $214(60.1 \%)$ & $27(65.9 \%)$ & $241(60.7 \%)$ \\
\hline Lack of skills & $92(25.8 \%)$ & $12(29.3 \%)$ & $104(26.2 \%)$ \\
\hline Low farm income & $37(10.4 \%)$ & $1(2.4 \%)$ & $38(9.6 \%)$ \\
\hline $\begin{array}{l}\text { Wealth } \\
\text { accumulation }\end{array}$ & $13(3.7 \%)$ & $1(2.4 \%)$ & $14(3.5 \%)$ \\
\hline Total & $356(100 \%)$ & $41(100 \%)$ & $397(100 \%)$ \\
\hline
\end{tabular}

Source: Field survey (2019)

During a focus group discussion with indigenous people in Nakori, it was realised that they diversified into non-farm livelihoods for survival. The following narration, which was derived from field notes, exemplifies the argument:

Women in the region are largely impoverished, and their inability to raise sufficient funds is exacerbated by dwindling access to land for agricultural activities and low wages from their diverse livelihoods. Diversified livelihoods such as stone mining help them fulfil a portion of their fundamental needs (Focus group discussant at Nakori, October 12, 2019). 
The preceding narrative demonstrates that aboriginal people perceived their limitations and resources before diversifying their livelihoods away from agriculture. The result corroborates the core argument of rational choice theory, that social actors such as indigenous women in peri-urban areas diversify their livelihoods in response to anticipated social outcomes under constraints such as income, wealth, properties, and control (Burns \& Roszkowska, 2016). This further supports the argument that poor families or people diversify their revenue sources to survive (Gebru et al., 2018).

Since respondents mentioned that they were engaged in farm and non-farm activities as livelihood diversification strategies, it was essential to know women's annual income from their farm livelihood activities. The results (Table 11) indicated that in 2005, the median income was GHS470.00 (At the time of study, GH $\$ 5.36$ was equivalent to US\$1.00), while in 2019, it was GHS300.00. In comparing the medians, it is noticed that the median farm income in 2005 was higher than that of 2019. This implies that at face value, the income of the women had reduced over the period. In addition, taking the average inflationary rate of $11.97 \%$ over the period 2005 to 2019 (Statista, n.d.), suggests that the farmer's real income has further dipped. Besides, a Wilcoxon signed ranked test was conducted to determine whether there were variations concerning annual farm income in 2005 and 2019. The results (Table 11) showed that the mean rank in 2005 was higher than that of 2019. The test was statistically significant at .05 alpha level $(Z=-4.98, p$-value $=.000)$. This suggests that farm income had declined over the period.

Table 11: Descriptive statistics of farm income and Wilcoxon signed-ranked test results

\begin{tabular}{|l|l|l|l|l|l|l|l|l|}
\hline Time & Number & Minimum & Maximum & Mean & $\begin{array}{l}\text { Standard } \\
\text { Deviation }\end{array}$ & Median & Skewness & $\begin{array}{l}\text { Quartile } \\
\text { deviation }\end{array}$ \\
\hline 2005 & 399 & 100 & 2000 & 592 & 349 & 470 & 1.49 & 176.25 \\
\hline 2019 & 399 & 100 & 1300 & 389 & 309.6 & 300 & 1.46 & 150 \\
\hline & $\begin{array}{l}\text { Mean } \\
\text { Ranks }\end{array}$ & Z-value & P-value & & & & & \\
\hline 2005 & 62.36 & -4.98 & 0.000 & & & & & \\
\hline 2019 & 57 & & & & & & & \\
\hline
\end{tabular}

Source: Field survey (2019)

Note: Income is in GHS; Significant at 0.05 alpha level

The annual income from non-farm enterprises was also analysed. The results (Table 12) revealed that in 2005 the median annual income was GHS300.00, which increased to GHS400.00 in 2019. A Wilcoxon signed ranked test was also carried out 
to determine whether differences existed in annual non-farm income in 2005 and 2019. The results indicated that the mean rank in 2019 was higher compared to that of 2005. The results (Table 12) showed that the test was significant at the five percent level $(z=1.35 ; p$-value $=.001)$. This implies that non-farm income had increased over the period.

Table 12: Descriptive statistics of non-farm income and Wilcoxon signed-ranked test results

\begin{tabular}{|l|l|l|l|l|l|l|l|l|}
\hline Time & Number & Minimum & Maximum & Mean & $\begin{array}{l}\text { Standard } \\
\text { Deviation }\end{array}$ & Median & Skewness & $\begin{array}{l}\text { Quartile } \\
\text { deviation }\end{array}$ \\
\hline 2005 & 399 & 30 & 1600 & 439.7 & 289 & 300 & 1.52 & 125 \\
\hline 2019 & 399 & 100 & 3,450 & 475.6 & 443 & 400 & 2.22 & 275 \\
\hline & $\begin{array}{l}\text { Mean } \\
\text { Ranks }\end{array}$ & Z-value & P-value & & & & & \\
\hline 2005 & 113 & 1.35 & 0.001 & & & & & \\
\hline 2019 & 135 & & & & & & & \\
\hline
\end{tabular}

Source: Field survey (2019)

Note: Income is in GHS; Significant at 0.05 alpha level

\section{Challenges Associated with Livelihood Diversification}

Even though peri-urban development creates an opportunity to diversify the portfolio of economic prospects available to indigenous women, such an exercise is not without challenges. Therefore, the study sought to find out whether respondents encountered challenges concerning diversifying their livelihood activities. Out of the 399 respondents, over two-thirds (72.3\%) of them noted they encountered challenges in their attempt to diversify their livelihoods, with the rest $(27.7 \%)$ not meeting any difficulty in that quest. Those that faced challenges in their bid to diversify their livelihoods enumerated the sources of their difficulties to cover stone mining, petty trading and charcoal making. For stone mining, respondents identified drudgery associated with digging for stones, injuries, long distance to the site, unavailability of land and a small amount of money earned from it. In connection with this, a participant in a FGD in Nakori (October 12, 2019) stated:

It has not been easy changing income sources from farming to stone mining. This was because the ground is hard and we have to dig using hoes and pick-axes. This is tiring, and at times in the process, some of us injure ourselves. Other times too, we go around picking the stones instead of digging. This takes a long time to get 
a substantial quantity that we can sell. Eventually, when we gather the quantity that is sellable over a week, we manage to get just a meagre GHS120.002 for a trip and making a profit of GHS30.00 only.

This quotation suggests that stone mining, as a livelihood diversification activity, is not without its difficulties. The challenges associated with petty trading encompass low patronage and the lack of access to large working capital, making it not very profitable. During a FGD in Sombo (October 14, 2019), a discussant also stated that "we do not get much out of petty trading business because of low demand for our wares as well as small working capital and as such, we are unable to expand our businesses." This suggests that livelihood diversification effort is restricted by demand and access to funding sources. Those who undertook charcoal making, mentioned the cutting down of shea trees, walking a long distance, and small earnings from the undertaking as the challenges encountered. Overall, these challenges tend to limit the women's gains from livelihood diversification, which is a demotivation to embarking on that quest. Yet, people have to diversify their livelihoods because it is a necessity. Consequently, the diversified livelihood activities are constrained, thereby, limiting their ability to utilise the available resources to eke out a living.

\section{CONCLUSIONS AND POLICY IMPLICATIONS FOR SUSTAINABLE DEVELOPMENT PLANNING}

Generally, the indigenous peri-urban women had observed physical changes in their communities manifested in increased residential housing and service infrastructure. These were driven by increased demand for land because of the relatively cheap cost of land in the peri-urban communities. This led to the construction of several residential houses in these areas, resulting in some of the completed houses not being occupied or partially occupied in the communities. However, peri-urban development had limited indigenous women's land access to undertake farming activities since most of the previously used lands for farming had been converted into residential, commercial and civic uses. Therefore, most women had lost the opportunity to earn farm income and had suffered production losses over the period. The only assets available to the women were their labour, access to economic trees, stone mining sites, markets and savings. Based on the assets available, the women pursued non-farm livelihood activities, including stone mining, petty trading, charcoal making and farming as livelihoods diversification 
activities to cope with the declining availability of lands for farming purposes. However, restricted demand and access to funding by the women served as obstacles to engaging in profitable business ventures. Besides, drudgery in digging for stones, injuries from stone mining, long distances to mining and charcoal sites, and non-profitability of the stone mining and charcoal making constituted challenges for those involved in stone mining and charcoal making.

The study draws on two key conclusions to make the following recommendations. First, urbanisation has significantly limited access to farmland and adversely affected farm livelihoods among indigenous women. Second, in response, women have resorted to the diversification of livelihoods and the pattern reveals a shift from farm-based livelihoods to non-farm livelihoods based on their circumstances amidst multiple constraints. Policy support for livelihood diversification among women within the context of decentralisation and municipal development planning is essential. Within the context of municipal development planning, the following specific policy initiatives can enhance livelihood sustainability among women:

The Municipal Assembly in collaboration with relevant non-governmental organisations could assist to enhance access to credit for investing in livelihoods activities through first community-based mobilisation such as the formation of self-help groups and village savings and loans associations for mobilization of finances for investments among members. Secondly, linking these self-help groups to government-supported microfinance institutions such as Microfinance and Small Loans Centre (MASLOC), special government programmes and rural banks to mobilise funding for investments and seeking training for improving skills of members for improving the running of various livelihoods.

The third specific policy initiative is for the Municipal Assembly to promote the introduction of intermediate technologies of production that first reduce drudgery associated with women's livelihoods and enhance their livelihoods and secondly, improve work safety by introducing protective work gears for women engaged in hazardous livelihoods.

The Municipal Assembly should promote the use of renewable energy for women into charcoal burning and wood-based livelihoods to help to achieve sustainable livelihoods, and at the same time meet energy needs of peri-urban indigenous women and the city at large. 


\section{REFERENCES}

Adell, G. (1999). Theories and models of the peri-urban interface: a changing conceptual landscape. Retrieved from https://discovery.ucl.ac.uk/id/ eprint/43/1/DPU PUIAdellT HEORI ESMODEL S.pdf

Adesoji, S. A., Olanrewaju, K. O., \& Kolawole, O. F. (2014). Livelihood diversification sources of female household heads in rural communities of Osun State. Journal of Agricultural Extension, 18(2), 10-20.

Ahmed, A., Korahb, P. I., Dongzaglaa, A., Nunboguc, A. M., Niminga-Bekad, R., Kuusaana, E. D., \& Abubakari, Z. (2020). City profile:Wa, Ghana. Cities, 97. https:// doi.org/10.1016/j.cities.2019.102524

Angeles, L.C., \&Hill, K. (2009). The gender dimension of the agrarian transition: women, men and livelihood diversification in two peri-urban farming communities in the Philippines. Gender, Place and Culture, 16(5), 609-629.

Appiah, D. O., Asante, F., \& Nketia, B. A. (2017). Perceived agricultural land use decisions in a peri-urban district, Ghana. Journal of Agricultural and Crop Research, 5(1), 1-10.

Burns, T., \& Roszkowska, E. (2016). Rational Choice theory: Toward a psychological, social, and material contextualization of human choice behaviour. Scientific Research, 6(2), 1-16.

Chambers, R., \& Conway, G. (1992). Sustainable rural livelihoods: Practical concepts for the 21st century. Brighton, UK: Institute of Development Studies.

Creswell, J. W. (2014). A concise introduction to mixed methods research. SAGE Publications.

Dekker, S. W. (2017). Rasmussen's legacy and the long arm of rational choice. Applied ergonomics, 59 (3), 554-557.

Dinku, A. M. (2018). Determinants of livelihood diversification strategies in Borena pastoralist communities of Oromia regional state, Ethiopia. Agriculture and Food Security, 7(1), 1-8.

Eledi, J. A., \& Kuusaana, E. D. (2014). Uncontrolled urbanisation in Ghana: A concern for food systems in the Wa Municipality. Journal of Sustainable Development Studies, 6(2), 260-293.

Ellis, F. (2000). The determinants of rural livelihood diversification in developing countries. Journal of Agricultural Economics, 51(2), 289-302.

Ellis, F., \& Allison, E. (2004). Livelihood diversification and natural resource access. Overseas Development Group, University of East Anglia. 
Gebru, G. W., Ichoku, H. E., \& Phil-Eze, P. O. (2018). Determinants of livelihood diversification strategies in Eastern Tigray Region of Ethiopia. Agriculture and Food Security, 7(1), 1-9.

Ghana Statistical Service. (2013). 2010 population and housing census: National analytical report. Accra: Ghana Statistical Service.

Ghana. Statistical Service. (2014). 2010 population and housing census: District analytical report, Wa Municipality. Accra: Ghana Statistical Service.

Habib, K., Shafiq, M., Afshan, G., \& Qamar, F. (2019). Impact of education and employment on women empowerment. European Online Journal of Natural and Social Sciences: Proceedings, 8(3), 62-74.

He. S., Liu, Y., Webster, C., \& Wu, F. (2009). Property rights redistribution, entitlement failure and the impoverishment of landless farmers in China. Urban Studies, 46(9), 1925-1949.

Johnson, R. B., \& Onwuegbuzie, A. J. (2004). Mixed methods research: A research paradigm whose time has come. Educational Researcher, 33(7), 14-26.

Kuusaana, E. D., Kidido, J. K., \& Halidu-Adam, E. (2013). Customary land ownership and gender disparity-evidence from the Wa Municipality of Ghana. Ghana Journal of Development Studies, 10(1-2), 63-80.

Marshall, F., \& Randhawa, P. (2017). India's peri-urban frontier: rural-urban transformations and food security. International Institute of Environment and Development (IIED).

Oduro, C. Y., Adamtey, R., \& Ocloo, K. (2015). Urban growth and livelihood transformations on the fringes of African cities: A Case study of changing livelihoods in peri-urban Accra. Environment and Natural Resources Research, 5(2), 81-98. http://dx.doi.org/10.5539/enrr.v5n2p81

Olsson, E. G. A., Kerselaers, E., Søderkvist, K. L., Primdahl, J., Rogge, E., \& Wästfelt, A. (2016). Peri-urban food production and its relation to urban resilience. Sustainability, 8 (12), 1-21.

Osumanu, I. K., Akongbangre, J. N., Gordon, N., Tuu, Y., \& Owusu-Sekyere, E. (2019). From patches of villages to a Municipality: Time, space, and expansion of Wa, Ghana. Urban Forum, 30(1), 57-74.

Perkins, D. D., \& Zimmerman, M. A. (1995). Empowerment theory, research, and application. American journal of community psychology, 23(5), 569-579.

Pigg, K. E. (2002). Three faces of empowerment: Expanding the theory of empowerment in community development. Community Development, 33(1), 107-123. 
Rafferty, J. P. (2009). Urban Sprawl. Encyclopaedia Britannica, September, 1.

Rijanta, R. (2015). The importance of peri-urban region in the diversification of rural yogyakarta, Indonesia. Regional Views, 28, 19-29.

Sato, Y. (2010). Rational choice theory. Sociopedia. isa 13(2), 1-10.

Scott, A. J. (2007). Capitalism and urbanization in a new key? The cognitive-cultural dimension. Tabula Rasa, 6, 195-217.

Sen, A. (2004). Capabilities, lists, and public reason: Continuing the conversation. Feminist economics, 10(3), 77-80.

Statista. (n.d.). Ghana: Inflation rate from 1985 to 2025. https://www.statista.com/ statistics/44757 6/inflation-rate-in-ghana/ (accessed on February 10, 2021)

Sudan, F. K. (2007). Livelihood diversification and women empowerment through self-help micro credit programme: Evidence from Jammu and Kashmir. Indus Journal of Management and Social Sciences, 1(2), 90-106.

Tassie, W. K. (2018). Determinants of peri-urban households' livelihood strategy choices: An empirical study of Bahir Dar city, Ethiopia. Cogent Social Sciences, 4(1), 1-22.

Wegedie, K. T. (2018). Determinants of peri-urban households' livelihood strategy choices: An empirical study of Bahir Dar city. Ethiopia. Cogent Social Sciences, 4(1), 1-22. https://doi.org/10.1080/23311886.2018.1562508

Woltjer, J. (2014). A global review on peri-urban development and planning. Journal of Regional and City Planning, 25(1), 1-16.

Zimmerman, M. A. (2000). Empowerment theory: Psychological, organizational and community levels of analysis. 